\title{
COMMUNITY DEVELOPMENT \\ DENGAN INSTRUMEN ZAKAT PROFESI \\ DI DESA JUMOYO, KECAMATAN SALAM, KABUPATEN MAGELANG
}

\author{
Mochlasin \\ Institut Agama Islam Negeri Salatiga \\ mocblas_sofyan@yahoo.co.id
}

\begin{abstract}
The purpose of this study was to determine how the implementation of community development programs using profession zakat that was proclaimed by Jumoyo Lor community, Jumoyo Village, District Salam, Magelang. This research includes field research based on case studies; the research was conducted intensive, detailed and indepth to an organization, institution or certain symptoms. Data was categorized then interpreted by a model interpretation surface structure and deep structure. Results of this study indicate that there has been a community development activity by relying on their own potential, by exploring the potential of zakat profession. At least the basic needs such as rice, shelter, bealth and education have been attempted to be fulfilled by the communities themselves, although in a minimal level
\end{abstract}

Keywords: Community development, zakat profession, tasharruf

\begin{abstract}
Abstrak
Tujuan penelitian ini adalah untuk mengetabui bagaimana implementasi program community development dengan instrument zakat profesi yang dicanangkan masyarakat Jumoyo Lor, Desa Jumoyo, Kecamatan Salam, Kabupaten Magelang. Penelitian ini termasuk jenis field research yang didasarkan pada studi kasus, yaitu penelitian yang dilakukan secara intensif, terinci dan mendalam terbadap suatu organisasi, lembaga atau gejala tertentu. Data yang sudah dikeategorikan kemudian diinterpretasikan dengan model interpretasi surface structure maupun deep structure. Hasil temuan penelitian ini menunjukekan bahwa telah terjadi aktivitas pengembangan masyarakat dengan bertumpu pada potensi sendiri, yaitu dengan mengeksplorasi potensi zakat profesi. Setidaknya kebutuhan dasar seperti beras, papan, kesehatan dan pendidikan telah dicoba untuk dipenubi oleh masyarakat sendiri, meskipun dalam level yang minimal.
\end{abstract}

Kata Kunci: Community development, zakat profesi, tasharruf 


\section{Pendahuluan}

Community development (pengembangan masyarakat) merupakan salah satu bentuk strategi pembangunan dalam manajemen negara modern, terutama di negara-negara berkembang sejak tahuan 1950an. Pembangunan masyarakat adalah sebagai upaya penyediaan kepada orang-orang atas sumber, kesempatan, pengetahuan, dan keterampilan untuk meningkatkan kemampuan mereka dalam menentukan masa depannya dan untuk berpartisipasi di dalam dan mempengaruhi kehidupan komunitas mereka (Ife, 1995: 182). Community development berarti masyarakat diberi wewenang untuk mengelola sendiri dana pembangunan baik yang berasal dari pemerintah maupun dari pihak lain, di samping itu mereka harus aktif berpartisipasi dalam proses pemilihan, perencanaan, dan pelaksanaan pembangunan (Sutrisno, 2000:185).

Cara pandang yang integral antara zakat sebagai domain keagamaan dan pembangunan sebagai domain kenegaraan di sisi lain, telah melahirkan cara pandang baru yaitu zakat sebagai instrumen community development (pengembangan masyarakat). Dengan demikian, zakat yang selama ini dipahahami pemanfaatannya hanya sebatas keperluan konsumtif telah dimaknai untuk kepentingan peningkatan kesejahteraan hidup yang lebih luas. Era baru pemaknaan masyarakat sebagai civil society, telah melahirkan partisipasi dari negara kepada masyarakat, masyarakat kepada negara dan dari masyarakat kepada masyarakat. Dalam situasi demikian, zakat mendapatkan momentum tafsir baru, meskipun dalam sejarah peradaban Islam zakat telah berfungsi untuk peningkatan kehidupan masyarakat secara keseluruhan.

Community development ini menjadi penting di saat kemiskinan masih menjadi problematika dalam kehidupan masyarakat Indonesia, baik di kota maupun di desa. Pemerintah dengan segala perhatiannya, baik berupa peningkatan anggaran maupun program-program pengentasan seperti bantuan langsung tunai, pendidikan, kesehatan dan pemberdayaan belum mampu menekan angka kemiskinan secara maksimal. Badan Pusat Statistik (BPS) menyatakan, pada bulan Maret 2014, jumlah penduduk miskin di Indonesia mencapai 28,28 juta orang, sekitar 11,25\%. Jika menggunakan standar Bank 
Dunia (kemiskinan moderat), yaitu berpenghasilan kurang dari 2 dolar (Rp 400.000,-)/bulan, maka kemungkinan jumlah penduduk miskin akan sangat fantastis yaitu mendekati angka 100 juta dari 250 juta penduduk Indonesia.

Realitas tersebut menyadarkan umat Islam untuk melakukan revitalisasi filantropi Islam dalam hal ini zakat. Zakat diharapkan mampu menjadi instrumen penting untuk menekan angka kemiskinan yang masih tinggi dan untuk mensejahterakan umat. Bentuk kesadaran itu ditunjukkan oleh umat Islam Indonesia dengan semakin meningkatnya perolehan zakat, baik berupa zakat fitrah, zakat harta benda (mal) maupun zakat profesi (zakah al-kasb). Hasil penelitian PPM UIN Syarif Hidayatullah dan Ford Foundation (2003), menunjukkan bahwa potensi dana ZIS (Zakat, Infak, Sedekah) umat Islam Indonesia yang dapat dimanfaatkan untuk kesejahteraan masyarakat mencapai Rp 19,3 triliun. Namun realisasinya menurut catatan BAZNAS, misalnya untuk tahun 2013 baru menembus angka 2,7 triliun.

Menyikapi masalah itu, masyarakat Desa Jumoyo, Kecamatan Salam, Kabupaten Magelang yang berada di lereng Gunung Merapi mencoba melakukan pembangunan masyarakat dengan mewujudkan pengelolaan zakat dan infak untuk membantu mensejahterakan kaum kurang mampu (dhuafa' dan mustad'afin). Dari paparan latar belakang tersebut, maka penelitian ini akan di fokuskan pada empat permasalahan sebagai berikut: (1) Apa latar belakang pendirian LAZIS? Dusun Jumoyo Lor, Desa Jumoyo, Kecamatan Salam, kabupaten Magelang? (2) Bagaimana mekanisme pengumpulannya? (3) Bagaimana mekanisme pentasarufannya? (4) Sejauhmana relevansinya pemanfaatan zakat sebagai instrumen community development?

\section{Zakat Profesi: Sebuah Ijtihad Sosial}

\section{Definisi Zakat Profesi}

Islam memandang zakat merupakan lambang pensyukuran nikmat, pembersihan jiwa, pembersihan harta, dan pemberian hak Allah, hak masyarakat, dan hak orang yang lemah. Perkembangan 
ekonomi modern dalam sektor pertanian, industri dan jasa mengharuskan untuk melakukan redefinisi tentang obyek harta yang harus dizakati. Sektor industri merupakan sektor yang terus mengalami peningkatan peran dan memberikan sumbangan yang semakin besar dalam perekonomian suatu negara. Tidak kalah menariknya dengan sektor industri terutama di Indonesia adalah perkembangan sektor jasa. Selain melahirkan sejumlah perusahaan di kalangan profesional, sektor ini juga banyak melahirkan bidangbidang usaha baru yang seringkali unik karateristiknya (Hafidhuddin, 2006: 89-90). Secara spesifik berdasarkan perkembangan perekonomian modern, maka sumber zakat yang dapat dipungut adalah: zakat profesi, zakat perusahaan, zakat surat-surat berharga, zakat perdagangan mat uang, hewan ternak yang diperdagangkan, madu dan produk hewani, investasi property, asuransi syariah, tanaman anggrek, ikan hias, burung walet, dan asesoris rumah tangga modern (Hafidhuddin, 2006: 93).

Menurut Yusuf Qardawi pekerjaan yang menghasilkan uang ada dua macam. Pertama, pekerjaan yang dikerjakan sendiri tanpa tergantung kepada orang lain, berkat kecekatan tangan ataupun otak. Penghasilan yang diperoleh dengan cara ini merupakan penghasilan profesional, seperti penghasilan seorang doktor, insinyur, advokat seniman, penjahit, tukang kayu dan lain-lainnya. Kedua, adalah pekerjaan yang dikerjakan seseorang buat pihak lain, baik pemerintah, perusahaan, maupun perorangan dengan memperoleh upah, yang diberikan, dengan tangan, otak, ataupun kedua- duanya. Penghasilan dari pekerjaan seperti itu berupa gaji, upah, ataupun honorarium (Qardhawi, 1991: 487).

Dalam fikih, harta yang dihasilkan dari aktivitas tersebut dikelompokkan sebagai al-mal al-mustafad. Sedangkam menurut Wahbah al-Zuhaili, zakat profesi (zakah al-kasb) pendapatan atau penghasilan yang diterima seseorang melalui usaha sendiri (wirausaha) seperti dokter, insinyur, ahli hukum, penjahit dan lain sebagainya (az-Zuhaili, 1997: 1948). Merujuk pada fatwa ulama yang dihasilkan pada Muktamar Internasioanl I tentang zakat di Kuwait tanggal 30 April 1984, zakat profesi adalah suatu kegiatan yang menghasilkan manfaat, baik yang dilakukan sendiri seperti dokter, arsitek dan lain-lain maupun yang dilakukan secara bersama-sama seperti para karyawan maupun pegawai. 
Dalam pandangan muslim Dusun Jumoyo Lor, Zakat profesi adalah zakat yang dikenakan pada tiap pekerjaan atau keahlian profesional tertentu yang mendatangkan penghasilan yang memenuhi nishab (batas minimum untuk berzakat) dan ditunaikan pada saat menerima. Pengertian ini nampaknya selaras dengan pendapat Qardhawi, al-Zuhaili maupun fatwa ulama dunia. Dasar al-Qur'an yang menjadi rujukan zakat profesi oleh para ulama adalah keumuman pada surat at-Taubah ayat 103, al-Baqarah ayat 267, dan adz-Dzariyat ayat 19 berikut ini:

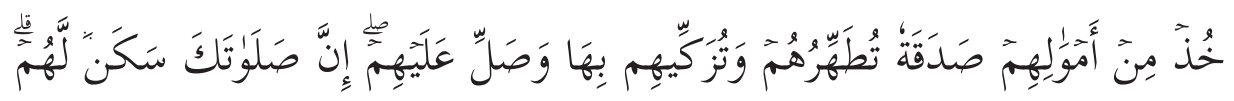 وَأللَّهُ سَمِيعُ عَلِيمُ}

"Ambillah zakat dari sebagian harta mereka, dengan zakat itu kamu membersihkan dan mensucikan mereka dan mendoalah untuk mereka."(QS. 9: 103).

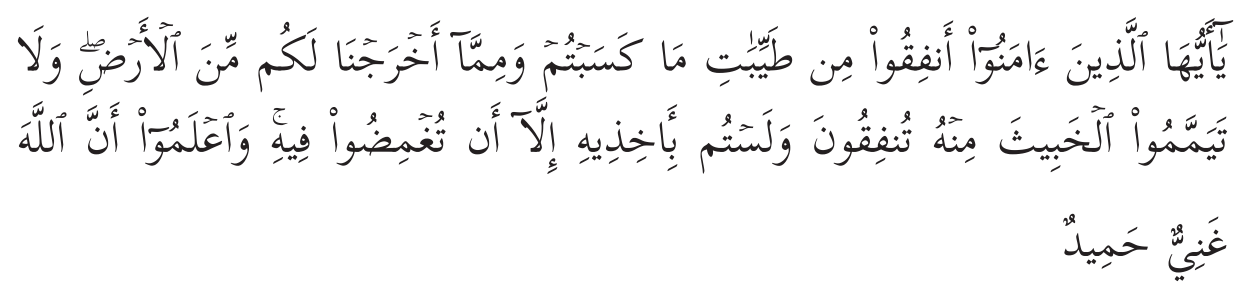

"Hai orang-orang yang beriman, nafkahkanlah (di jalan Allah) sebagian dari hasil usahamu yang baik-baik dan sebagian dari apa yang kami keluarkan dari bumi untuk kamu."(QS. 2: 267).



"Dan pada harta-harta mereka ada hak untuk orang miskin yang meminta dan orang miskin yang tidak mendapat bagian."(QS.51: 19). 
Dari ayat-ayat tersebut dapat ditarik suatu kesimpulan, harta yang harus dikeluarkan zakatnya adalah seluruh hasil usaha manusia yang baik dan halal serta seluruh yang dikeluarkan Allah dari muka bumi seperti pertanian, pertambangan (minyak, gas dan lain-lain). Oleh karenanya, ayat ini melingkupi harta benda yang ada pada zaman Rasulullah dan harta benda yang bersumber dari sesuatu yang tidak ditemui pada zaman Rasulullah. Kebanyakan ulama sepakat, bahwa kewajiban zakat profesi setelah memenuhi syarat nishab (85 gram emas) maka zakatnya $2,5 \%$. Perbedaan terjadi pada teknis waktu pengeluarannya terutama untuk pegawai, yaitu setiap bulan atau setiap tahun. Pendapat ini juga yang menjadi acuan dari UU No. 38/1999 tentang Pengelolaan Zakat. Menurut pasal 11 ayat (2), harta yang dikenai zakat adalah emas, perak dan uang, perdagangan dan perusahaan, hasil pertanian/ hasil perkebunan/ hasil perikanan, hasil pertambangan, hasil peternakan, hasil pendapatan dan jasa, serta rika\%:

Barangkali terlalu banyak untuk disebutkan literatur yang membahas tentang zakat secara teoritik. Afzalur Rahman adalah ilmuwan muslim Pakistan yang cukup komprehensif menulis tentang zakat dalam bahasa Inggris, Economic Doctrines of Islam (1995) sebanyak empat jilid. Meskipun judul tersebut tidak menyebut secara langsung istilah zakat, namun pembahasan tentang zakat ditulis sebanyak empat bab. Rahman membahas persoalan-persoalan zakat yang aktual terjadi meskipun setting Pakistan tentunya sangat mempengaruhi. Di antara masalah menarik yang dibahas adalah (1) zakat merupakan pajak atau kewajiban agama; (2) tanggung jawab negara terhadap pelaksanaan zakat; (3) redefinisi dan pembangunan makna mustahiq; (3) masalah pendistribusian dan hukum Pareto beserta asumsinya; (4) perbedaan konsep zakat dan prinsip perpajakan.

Penelitian yang memfokuskan pada masalah penghimpunan dan pengelolaan zakat yang dipublikasikan ditulis oleh Nukhthoh Arfawie Kurdie dalam Memungut Zakat dan Infaq Profesi (2005). Obyek penelitian ini adalah Kota Samarinda Provinsi Kalimantan Timur. Rumusan masalah dalam penelitian iani adalah (1) apakah profesi pegawai negeri dan pegawai perusahaan daerah dapat digolongkan sebagai profesi potensi zakat?; (2) siapakah atau badan apakah yang wajib memungut dan mengelolanya?. Temuan penelitian ini adalah di antaranya adalah: (1) pemerintah wajib memungut dan mengelola 
zakat, infaq sedekah umat secara profesional, jujur amanah dan transparan. Penelitian lain dilakukan oleh Supardi Productive Zakat dan Poverty Alleviation (Zakat Produktif dan Pengentasan Kemiskinan). Obyek penelitian ini adalah Pos Keadilan Peduli Umat (PKPU) Jawa Tengah. Temuan pene;itian ini adalah: (1) PKPU Jawa Tengan melsksanakan zakat produktif denagn berbagai program pemberdayaan kepada mustahiq, dengan target para mustabiq dapat berubah status menjadi muzakk;. (2) kendala utama yang dihadapi oleh PKPU Jawa Tengah adalah terbatasnya dana zakat dikarenakan rendahnya kesadarah untuk membayar zakat.

Penelitian tentang pengelolaan zakat juga dilakukan oleh Asnaini dengan judul Zakat Produktif dalam Hukum Islam: Studi Terbadap Pemberian Dana Bergulir dalam Program Masyarakat Mandiri Dompet Dhuafa Republika Jakarta (2007). Temuan penelitian ini adalah: (1) lembaga zakat Dompet Dhuafa Repubilka Jakarta adalah lembaga yang melaksanakan zakat produktif, salah satu bentuknya pemberian dana bergulir kepada kelompok Masyarakat Mandiri (MM); (2) kemandirian ekonomi masyarakat adalah tujuan utama dari program MM, sehingga progaram ini diarahkan untuk mendidik dan melatih masyarakat untuk selalu berproduksi.

Penelitian tentang pengelolaan zakat dalam bentuk skripsi juga banyak ditemukan, misalnya: Baidlowi (2003), Potensi Bazis untuk Meningkatkan Kesejabteraan Masyarakat di Kabupaten Sleman Yogyakarta, Hosnu El Wafa (2003) Konsepsi Zakat Produktif dalam Pemikiran Syekh Muhammad Arsyad Al Banjari. Alfiya Nur Hasanah, (2005) Hubungan Zakat terhadap Tingkat Kemiskinan pada BAZ Propinsi DIY Tahun 19992003", Ulin Ulfa (2005) Pendayagunaan Zakat untuk Usaba Produktif (Kajian Terhadap Pasal 16 Ayat 2 UU no.38 Tahun 1999 Tentang Pengelolaan Zakat), Hazamih (1998) Pengelolaan Zakat pada BAZ DKI Jakarta.dan lain-lain. Nurlaily Fitriati Kritik terbadap UndangUndang No. 38 Tabun 1999 tentang Pengelolaan Zakat, dan Al Ghaffar dengan topik Efektifitas UU No. 38 Tabun 1999 Tentang Pengelolaan Zakat (Studi di Badan Amil Zakat (BAZ) Kabupaten Malang). Dalam bentuk tesis ditulis oleh Musta'in Ahmad (Program Pasca UNS Surakarta) dengan judul Pelaksanaan Undang-Undang No. 38 Tabun 1999 tentang Pengelolaan Zakat di Kota Surakarta (Suatu Kajian dari Segi Hukum, Kebijakan dan Birokrasi). 
Penelitian terbaru dilakukan oleh Mochlasin dengan judul "Dampak Penerapan Good Corporate Governance terhadap Peningkatan Kinerja Pengelola Zakat di Badan Amil Zakat Kota Yogyakarta)". Adapun temuan penelitian ini bahwa dampak dari penerapan prinsip-prinsip GCG, tentu berdampak pada kinerja pengelola yang terukur dalam kinerja yang berupa: 1) meningkatnya kesadaran para pegawai dalam penunaian zakat profesi; 2) meningkatnya fungsi dan peranan Badan Amil Zakat dalam upaya mewujudkan kesejahteraan masyarakat dan keadilan sosial; 3) meningkatnya hasil guna dan daya guna zakat yang dalam realitas konkrit. Dari penelitian-penelitian terdahulu, baik yang sudah terpublikasi maupun tidak terpublikasi belum dijumpai penelitian tentang zakat sebagai instrumen community development.

\section{Comunity Development}

Di tengah-tengah laju pertumbuhan ekonomi yang cukup mengembirakan saat ini, masih banyak terjadi kemiskinan an penggangguran. Faktor-faktor penyebabnya adalah kecilnya akses terhadap pasar dan sumber daya, lemahnya kemampuan sumberdaya alam dan sumberdaya manusia, struktur sosial yang tidak seimbang serta urban dalam proses pengambilan keputusan dan alokasi dana (Soetomo, 2008: 5). Konsep community development banyak dirumuskan di dalam berbagai definisi. Perserikatan Bangsa-Bangsa menurut Einsiedel sebagaimana dikutip oleh Suharto (1997: 98), mendefinisikan pengembangan masyarakat merupakan suatu proses dimana usaha-usaha atau potensi-potensi yang dimiliki masyarakat diintegrasikan dengan sumber daya yang dimiliki pemerintah, untuk memperbaiki kondisi ekonomi, sosial dan kebudayaan, dan mengintegrasikan masyarakat di dalam konteks kehidupan berbangsa, serta memberdayakan agar mampu memberikan kontribusi secara penuh untuk mencapai kemajuan pada level nasional.

Definisi lebih komprehensif menyatakan bahwa community development sebagai suatu proses di mana masyarakat yang tinggal pada lokasi tertentu mengembangkan prakarsa untuk melakukan suatu tindakan sosial, baik disertai intervensi pemerrintah maupun tidak untuk mengubah situasi ekonomi, sosial, kultural atau 
lingkungan (Christenson dan Robinson, 1989: 14). Dari pemaparan itu, terdapat beberapa prinsip dalam community development berikut ini (Soetomo, 2008: 82):

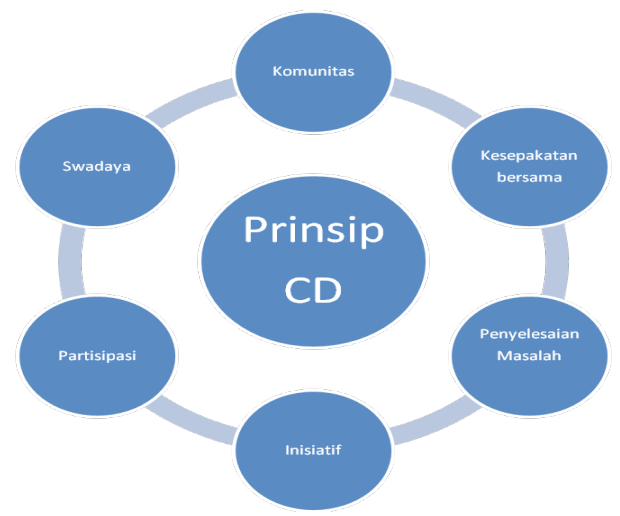

Selanjutnya cara kerja program community development dapat berjalan dalam masyarakat yang kompeten. Kompetensi inilah yang nantinya suatu masyarakat melakukan tugas pengembangan dalam rangka meningkatkan kesejahteraan lahir batin (Ndraha, 1987: 58). Kerangka kerja tahap ketiga menurut Ndraha adalah adanya kesepakatan media yang digunakan, salah satu yang bias digunakan adalah zakat profesi. Instrumen ini yang kemudian untuk membuat serangkaian program kerja bersama seperti ekonomi, kesehatan, dakwah, kesehatan dan penyediaan sarana dan prasarana.

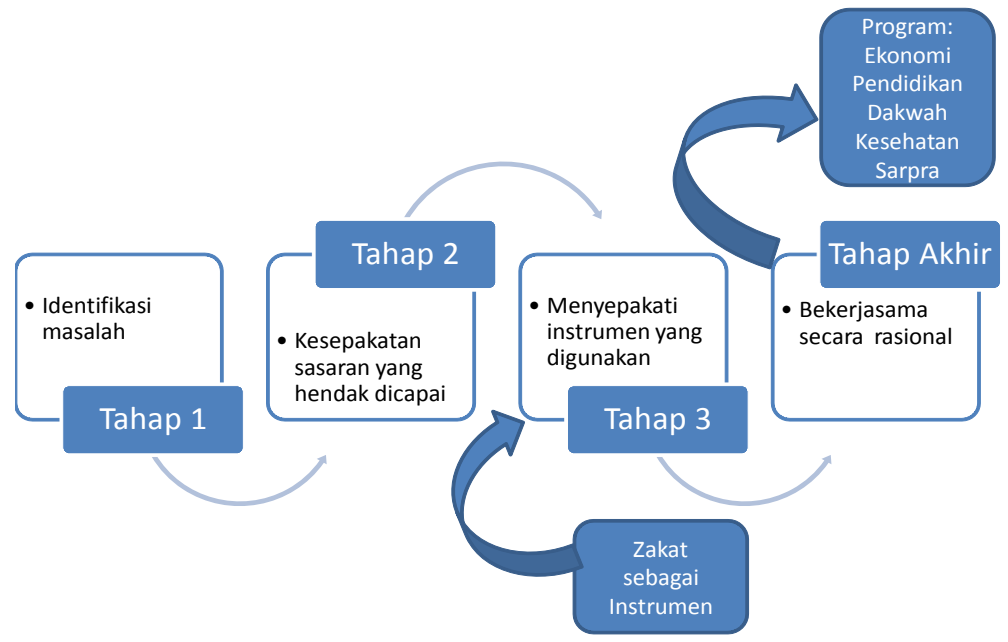




\section{Metode Penelitian}

\section{Jenis Penelitian}

Penenlitian ini termasuk jenis penelitian lapangan (field research) yang didasarkan pada studi kasus, yaitu penelitian yang dilakukan secara intensif, terinci dan mendalam terhadap suatu organisasi, lembaga atau gejala tertentu (Arikunto, 1998: 9).

\section{Lokasi Penelitian}

Lokasi penelitian ini adalah Dusun Jumoyo Lor, Desa Jumoyo, Kecamatan Salam, Kabupaten Magelang. Di desa Jumoyo sebenarnya terdapat 13 Dusun, Alasan pemilihan lokasi ini dikarenakan desa ini telah melaksanakan program zakat sebagai instrumen community development melalui lembaga Lembaga Amil Zakat, infaq dan sodaqah (LAZIS). Hal itu didapat peneliti dari informasi lisan dan pemberitaan di suarat kabar. Adapun subyek penelitian ini adalah para pengurus LAZIS, muzakki dan mustabiq.

\section{Teknik Pengumpulan Data}

Pada penelitian ini peneliti menggali data primer dan data sekunder dengan menggunakan metode:

1. Pengamatan (observasi)

Metoda pengamatan digunakan untuk memperoleh informasi mengenai gejala-gejala yang dalam kehidupan sehari-hari dapat diamati. Hasil pengamatan biasanya didiskusikan oleh si peneliti dengan warga masyarakat yang bersangkutan untuk mengetahui makna yang terdapat dibalik gejala-gejala tersebut (Suparlan 1997: 103).

\section{Wawancara}

Dalam hal ini Peneliti mengadakan wawancara dengan tokoh lembaga atau para fungsionaris khususnya pihak manajemen LAZIS Dusun Jumoyo yang berkompeten dan representatif dengan masalah yang diteliti untuk memperoleh informasi mengenai penghimpunan, pendistribusian dan fungsi zakat sebagai community development. 


\section{Dokumentasi}

Metode ini dilakukan untuk mengeksplorasi data sekunder yang dikumpulkan melalui koleksi media, arsip, dokumen dan referensi yang terkait dengan penelitian ini. Data-data di atas diperoleh melalui instansi dan atau lembaga yang relevan dan mempunyai keterkaitan dengan tema penelitian ini (Soehadi, 1999: 59).

\section{Teknik Analisis Data}

Data-data yang diperoleh yang berkenaan dengan penelitian baik dari pengamatan dan wawancara maupun dokumen dipilah berdasarkan kelompoknya. Data yang sudah dikategorikan kemudian diinterpretasikan dengan model interpretasi surface structure maupun deep structure. Dari interpretasi ini kemudian dikembangkan ke interpretasi deep structure, yaitu interpretasi yang mengungkap maknamakna tersirat di balik penjelasan informan, maupun aktivitasaktivitas yang dilakukan para pengurus LAZIS Dusun Jumoyon, murakki dan mustahiq.

Dalam pengumpulan data, besar sekali kemungkinan terjadinya distorsi data. Untuk mengeliminasi ketidaksahihan data yang masuk, maka dilakukan kritik dengan cara crosscheck data. Hal ini dengan mencocokkan hasil wawancara antara informan yang satu dengan informan lainnya. Dari crosscheck data ini kemudian dianalisis data mana yang mempunyai akurasi kebenaran paling tinggi.

\section{Analisis}

\section{Profil Dusun Jumoyo Lor}

Desa Jumoyo berbatasan dengan empat desa tetangga, yaitu sebelah utara berbatasan dengan Srumbung, sebelah selatan dengan Desa Seloboro, sebelah timur dengan Desa Sucen dan sebelah barat dengan Desa Gulon. Desa ini termasuk Kecamatan Salam yang berbatasan dengan Kecamatan Srumbung, Ngluwar, Muntilan dan Tempel, Kabupaten Sleman, Yogyakarta. Desa ini memiliki luas 641.874 yang terdiri dari tanah pekarangan, perkebunan dan 
persawahan (Diolah dari Data Kelurahan). Adapun Dusun Jumoyo Lor yang menjadi obyek penelitian ini adalah salah satu dari 13 dusun yang berada di wilayah Desa Jumoyo. Dusun-dusun itu adalah Dusun Jumoyo Kidul, Seloiring, Pendem, Gempol, Kembaran, Dowakan, Kemiren, Wironayan, Babadan, Pulosari dan Rename. Keberadaan Dusun Jumoyo Lor sesuai dengan namanya, berada di sebelah utara jalan raya Magelang-Yogyakarta.

Wilayah desa Jumoyo terdiri kampung-kampung bernuansa pedesaan nan asri mengingat sebagaian besar kampung di desa Jumoyo dikelilingi tanah perkebunan yang luas hampir setiap dusun dapat dengan mudah dijumpai tanah perkebunan yang banyak ditanami tanaman tropis seperti bambu, pohon rambutan, tanaman salak dan sejumlah pohon tropis lainnya (mywapblog.com/mengenaldekat-desa-jumoyokecamatan-sala.xhtm ).

Jumlah penduduk saat ini sebanyak 7.311 orang dengan 2.160 Kepala Keluarga. Sebanyak 98\% penduduk Jumoyo memeluk agama Islam. Penduduk desa Jumoyo umumnya berprofesi sebagai petani, petani salak, buruh, pedagang dan profesi lainnya. Di Dusun Jumoyo Lor ditilik dari tingkat pendidikan terdapat 2 orang tidak tamat SD, tamat SLTA 153 (92 laki-laki/61 perempuan), S1 32 orang (20 laki-laki/12 perempuan dan S2 satu orang.

\section{Latar Belakang Berdirinya LAZIS Dusun Jumoyo Lor}

Ide pembentukan lembaga zakat mulanya datang dari beberpa muzakki yang kemudian oleh Kepala Desa Jumoyo, Sungkono dijadikan kebijakan pemerintahan desa. Oleh karena tidak heran kalau tiga belas dusun yang ada di wilayah Desa Jumoyo, tinggal empat dusun yang belum memiliki lembaga zakat yaitu Dusun Pendem, Selo Iring,Jumoyo Kidul, dan Babadan. Pembentukan panitia zakat (amil) ini juga didasari pertimbangan Alokasi Dana Desa (ADD) saat itu berkurang dari semula Rp99 juta menjadi Rp63 juta. Padahal dana itu menjadi tumpuan membangun desa dan masyarakat berharap semua pembangunan dibiayai dari ADD. Setelah dibentuk 'amil (pengurus zakat), anggotanya "disekolahkan" pada KH Raden Muhaimin Asnawi tentang zakat (www.koransindo.com). 
Setelah warga mengerti tentang zakat, dibentuklah lembaga zakat dengan model pembayaran secara takjil. Takjil artinya nyicil (kredit), zakat dari warga yang wajib mengeluarkannya dibayarkan dan diambil amil di rumahnya setiap bulan mulai tanggal 1-15. Semestinya zakat profesi masyarakat ini dihitung dalam satu tahun tapi disepakati tiap satu bulan. Sesuai hukum Fikih Islam, zakat profesi orang yang memiliki pekerjaan dan penghasilan ini adalah 2,5\% dari penghasilannya (www.koransindo. com).

Anjuran dari kelurahan untuk mendirikan lembaga zakat di respon positif oleh para tokoh agama dan para aktivis masjid untuk mendirikan lembaga zakat. Mulanya warga dikumpulkan untuk membahas masalah zakat dan ternyata kesadaran sebagain warga Dusun Jumoyo Lor cukup tinggi. Maka pada tahun 2008, didirikanlah Lembaga Amil Zakat Infaq dan Sodaqah (LAZIS). Kepengurusan LAZIS Dusun Jumoyo dikomandani oleh Lukman Arifin dan sekretaris Khoirul Wakhid. Pelantikan kepengurusan dilaksanakan pada acara keagamaan desa yaitu pengajian 10 Muharam tahun 2008.

Respon positif itu didasarkan pada tiga hal: 1)Mayoritas warga dusun Jumoyo lor adalah muslim dengan prosentase mendekati 99\% dan memiliki kesadaran keagamaan tinggi; 2)Masih banyaknya warga yang sangat membutuhkan bantuan untuk memenuhi kebutuhan dasar seperti makan, kesehatan dan pendidikanr; 3) Karakter masyarakat pedesaan yang guyub rukun (memiliki solidaritas), dan budaya tolong menolong yang masih menjadi tradisi.

\section{Susunan Pengelola ('Amil)}

Pengurus LAZIS Dusun Jumoyo Lor berjumlah 25 orang yang terdiri dari tokoh masyarakat dan perwakilan RT yang berjumlah tujuh orang. Kepengurusan pertama dilantik pada tun 2008 dan berakhir tahun 2011, usia periode kepemimpinan adalah tiga tahun. Kepengurusan saat ini di bawah kendali Luqman Arifin adalah generasi yang kedua. Susunan kepengurusan terdiri dari pelindung, penasehat ketua 1 dan 2, sekretaris 1 dan 2, bendahara 1 dan 2, seksi penarikan dan pentasharufan dari tiap RT dan seksi kesehatan. Dari segi pendidikan, hanya ada satu pengurus yang sudah berpendidikan sarjana. Selebihnya berpendidikan tingkat SLTA atau masih kuliah 
dan selebihnya untuk kalangan tua hanya SD. Para pengelola zakat di Desa Jumoyo umumnya dan Dusun jumoyo Lor khususnya, dengan difasilitasi kelurahan melaksanakan semacam Workshop manajemen zakat dengan narasumber dari BAZDA Kabupaten Magelang. Untuk menindaklanjuti kemampuan mengelola zakat, masyarakat Dusun Jumoyo Lor juga menyelenggarakan sendiri pelatihan dengan narasumber dari BAZDA Kabupaten Magelang. Berikut struktur pengelola zakat ('ami) di Dusun Jumoyo Lor:

\begin{tabular}{|c|c|}
\hline Pelindung & : Kadus Jumoyo Lor \\
\hline Penasehat & : H.Sungkono \\
\hline Ketua I & : Lukman Arifin \\
\hline Ketua II & : Drs. Achmad Barisun \\
\hline Sekretaris I & : Muadzin Widodo \\
\hline Sekretaris II & : Lutfi Andi Aris \\
\hline Bendahara I & : Chirul Wahid \\
\hline Bendahara II & : Musyafak M,Pd \\
\hline \multicolumn{2}{|c|}{ Seksi Penarikan dan Pentasarufan } \\
\hline & : RT 01 Ashari, Komarudin \\
\hline & : RT 02 Rujito, Yahya Ibrahim \\
\hline & ; RT 03 Sholihin, Chalimi \\
\hline & : RT 04 Mufid, Widodo \\
\hline & : RT 05 Basori, Chorul Imam \\
\hline & : RT 06 M.Fadil, Ashari \\
\hline & : RT 07 Munirudin, Nur Slame \\
\hline \multirow[t]{2}{*}{ Seksi Kesehatan } & : HM. Dahrowi \\
\hline & : Ramadhan \\
\hline
\end{tabular}

Kriteria Muzakki dan Mustahiq menurut LAZIS Dusun Jumoyo Lor

Muzakki yang dipahami oleh pengelola LAZIS adalah warga Dusun Jumoyo yang memiliki pekerjaan tetap maupun serabutan. Seperti telah ditulis pada demografi Desa Jumoyo, bahwa pekerjaan warga Dusun Jumoyo adalah umumnya buruh dan petani, 
meskipun terdapat yang berprofesi sebagai pedagang dan PNS. Menurut pemahaman masyarakat muslim Dusun Jumoyo, ketentuan menunaikan zakat tidak dibatasi dengan ketentuan minimal (nisab) sebagaimana pemahaman dalam fikih kebanyakan. Kehidupan yang sederhana masyarakat Dusun Jumoyo yang membuat profesi apapun, mejadikan mereka mampu menempatkan sebagai muaakki.

Cara pandang religius di atas, tentunya akan berbeda dengan masyarakat perkotaan yang cenderung memiliki kebutuhan hidup yang beragam. Dalam masyarakat perkotaan, tentunya profesi buruh belum selayaknya menjadi muzakeki. Kondisi demikian, bahkan menurut ketua LAZIS, membuat para warga pendatang menjadi heran karena selain zakat profesi ada pengeluaran lainnya seperti infak, iuran RT, iuran acara keagamaan, mantenan dan lain-lain. Jumlah nominal zakat terbesar sebesar Rp 900.000,- dan terendah Rp 25.00,-. Berikut jumlah muqakki dari setiap RT:

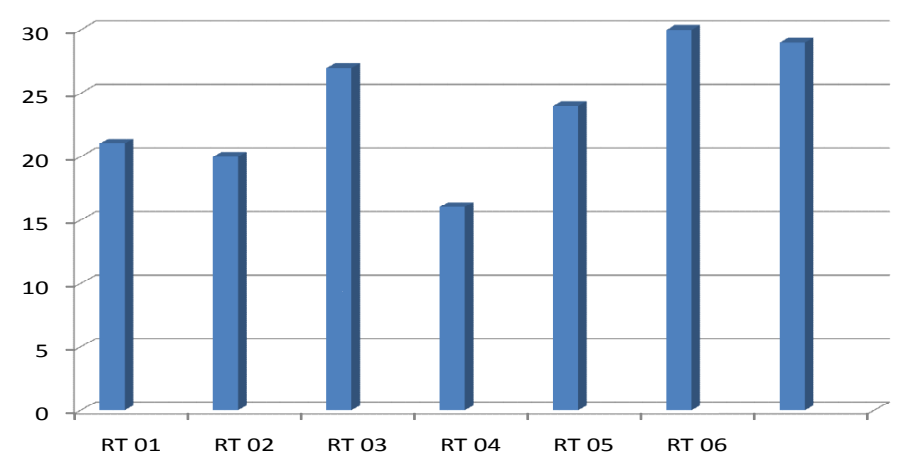

LAZIS Dusun Jumoyo memahami kelompok penerima zakat (mustabiq) sebagaimana tercantum dalam surat at-Taubah secara hirarkis, artinya kelompok pertama yaitu fuqara' adalah harus diutamakan. Kelompok fuqara' ini diistilahkan dengan miskin tak tak berdaya, yaitu mereka yang tidak bisa bekerja karena usia maupun cacat tubuh. Data tentang miskin tak berdaya tidak mengacu pada sensus masyarakat miskin dari pemerintah, tetapi survey yang dilakukan oleh para relawan zakat langsung sehingga validitasnya mendekati 100\%. Mengingat keterbasan jumlah zakat yang dihimpun, maka kelompok ini yang baru bisa diupayakan miskipun tidak bisa menanggung keseluruhan kebutuhan hidup 
mustahiq. Di Dusun Jumoyo jumlah kategori miskin tidak berdaya sebanyak 10 orang, yang terdiri 3 laki-laki dan 7 perempuan.

\section{Zakat Profesi sebagai Instrumen Community Development}

1. Penghimpunan Zakat Profesi

Melalui pengajian dan kegiatan keagamaan lainnya, masyarakat disadarkan oleh para penggerak zakat untuk selalu ingat terhadap kewajibvannya. Dari beberapakali pertemuan antara tokoh masyrakat dan para pemuda, tercetuslah perlunya menunaikan zakat mal dan lebih khusus lagi zakat profesi. Untuk memudahkan pengumpulan dan sekaligus sebagai sarana mengingatkan, dibuatlah kotak papan zakat dengan ukuran kurang lebih $15 \times 15 \mathrm{~cm}$ dari papan. Kotak ini terdiri dua bilik berwarna hijau tua, yaitu bilik zakat dan bilik infak. Pembuatan kotak dengan dua bilik ini, menunjukkan pengelola khususnya dan masyarakat umumnya memahami bahwa zakat adalah pengeluaran wajib sedangkan infaq adalah pengeluaran sunah. Pemahaman ini jelas terlihat dari perbandingan perolehan keduanya, zakat selalu lebih banyak jumlahnya daripada infaq.

Setiap tanggal 15, sejumlah 20 relawan yang statusnya adalah pengelola zakat ('amil) jemput bola untuk mengambili kotak dari para warga yang tergolong muzakki. Perilaku muzakki warga dusun Jumoyo sangat beragam: Pertama: Bagi yang berpenghasilan tetap seperti PNS akan langsung menyisihkan 2,5\% dari penghasilan dengan cara memasukkan kotak atau bayar langsung pada relawan. Kedua, muzakki yang semi tetap seperti tukang galian pasir, tukang kayu dan tukang batu akan membayar dengan memotong 2,5\% dari penghasilan sehingga ada perhitungan yang jelas. Ketiga, bagi muzakki yang berpenghasilan tidak tetap seperti pedagang biasanya akan memotong 2,5 dari penghasilan setiap harinya sehingga dalam rentang sebulan muzakki sendiri tidak mengetahui jumlah nominal dalam kotak zakat. 
Cara memasukkan zakat profesi dalam kotak zakat setiap hari inilah barangkali yang kemudian dikenal di kalangan warga sebagai Takjil Zakat (cicilan Zakat). Dengan kotak zakat muzakki akan memiliki rasa tanggung jawab terhadap kewajibannya dan tidak berani untuk menggunakan untuk keperluan yang lain, kecuali keperluan mendesak. Dengan bentuk cicilan ini juga terasa ringan bagi muzakki. Menurut Luqman, ketua LAZIS Dusun Jumoyo Lor, muzakki yang berprofesi sebagai tukang galian pasir dengan upah Rp 100.000,- perhari, maka dia akan menghitung dengan cara $\mathrm{Rp} 100.000,-\mathrm{x} 2,5 \%=\mathrm{Rp} 2.500,-\mathrm{x} 1$ bulan (30 hari) $=\operatorname{Rp} 75.000$. namun menurut Pak luqman, hitungan ideal ini umumnya belum bisa dipenuhi oleh muzakki. Dengan kewajiban zakat profesi berdasarkan hitungan Rp 75.000,-, bisanya muzakki hanya kan memberikan sekitar Rp 30.000-50.000,- atau sekitar 40 \%- 60\%. Sehingga perhitungan pengelola, seandainya muzakki secara ideal menunaikan zakat profesinya, penghimpunan akan mengalami lonjakan sebesar 50\%. Di samping zakat profesi yang rutin, pernah ada warga yang mengeluarkn zakat mal sebesar Rp 10.000.000,- karena mendapat ganti rugi tanah untuk pembangunan jembatan Kali Putih baru.

Setelah kotak zakat diambil oleh relawan tiap tanggal 15, kemudian mereka kumpul di rumah mantan kades bapak Sungkono. Uang dihitung berdasarkan kategori zakat dan infak serta tidak boleh bercampaur, karena dalam pemahan pengelola zakat dan infak telah memiliki pos-pos penggunaan yang berbeda. Dusun Jumoyo Lor terdiri tujuh RT, rata-rata setiap bulan bisa mengumpulkan kurang lebih 3.000.000,-. Pelaporan LAZIZ biasanya disusun dalam satu buku dengan infak karena penarikannya bersamaan dalam kotak papan. 


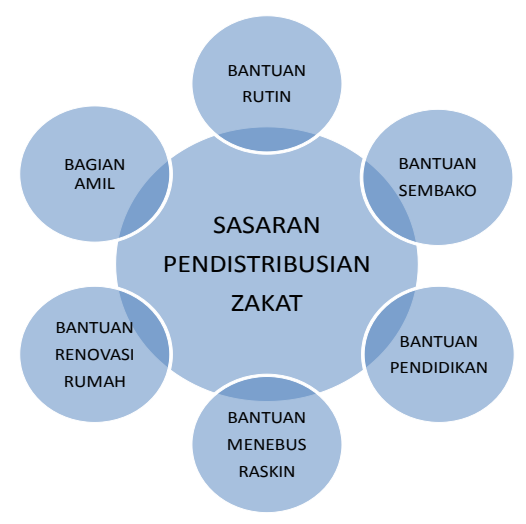

2. Obyek Pentasyarufan

Pentasarufan danazakat profesi diDusun Jumoyo diperuntukkan untuk tiga bagian mustahiq yaitu fuqara', masakin dan 'amil yang dikemas dalam lima program kegiatan yaitu:

a. Bantuan rutin

Bantuan rutin sebesar Rp 50.000,- diberikan kepada kelompok miskin tak berdaya. Yaitu mereka yang tidak memiliki pekerjaan karena secara fisik tidak memungkinkan. Bantuan ini diberikan tiap tanggal 15 setelah pengambilan dari para muzakeki. Warga yang berada dalam kelompok ini berjumlah 10 orang yang kebanyakan janda.

b. Bantuan sembako

Bantuan sembako sasarannya diperluas, kelompok miskin tak berdaya ditambah warga yang memiliki pekerjaan tetapi masih kekurangan. Paket sembako diberikan menjelang puasa dengan tujuan agar mustahiq dapat menjalankan ibadah puasa dengan khusus'. Penerima paket ini sebanyak 47 orang. Adapun paket sembako berupa beras $10 \mathrm{~kg}$, minyak 0,5 lt, $1 \mathrm{~kg}$ gula pasir.

c. Bantuan pendidikan

Bantuan pendidikan berupa uang sejumlah Rp 200.000,diberikan tiap menjelang tahun ajaran baru. Pemberian ini didasarkan pertimbangan bahwa menjelang tahun 
ajaran baru kebutuhan untuk sekolah cukup tinggi. Paket ini diberikan anak-anak dari keluarga miskin sebanyak 25 orang.

d. Bantuan menebus raskin

Sebagaimana di daerah lain, warga Dusun Jumoyo juga mendapat bantuan beras miskin (raskin) sebanyak $20 \mathrm{~kg}$. Untuk menebus raskin di kelurahan, biasanya dikenai biaya sebesar Rp 10.000,-. LAZIS menanggung uang tebusan tersebut sehingga warga dapat memperoleh dengan gratis.

e. Bantuan renovasi rumah

Bantuan renovasi rumah dari LAZIS sifatnya tidak rutin, tetapi didasarkan pada keperluan yang mendesak. Setidaknya tiga kali LAZIS memberi bantuan warga miskin yang rumahnya perlu dibedah. Biasanya tenaga renovasi berupa bantuan suka rela dari warga.

f. Bagian 'amil

'Amil LAZIS adalah para pengelola zakat profesi yang berjumlah 25 orang. Hak 'amil diberikan berupa Adapun paket sembako berupa beras $10 \mathrm{~kg}$, minyak 0,5 lt, $1 \mathrm{~kg}$ gula pasir yang dibagikan menjelang bulan Ramadhan.

Dari paparan di atas, maka implementasi program community development di Dusun Jumoyo Lor dengan menggunakan instrument zakat dapat diilustrasikan dalam bagan berikut ini: 


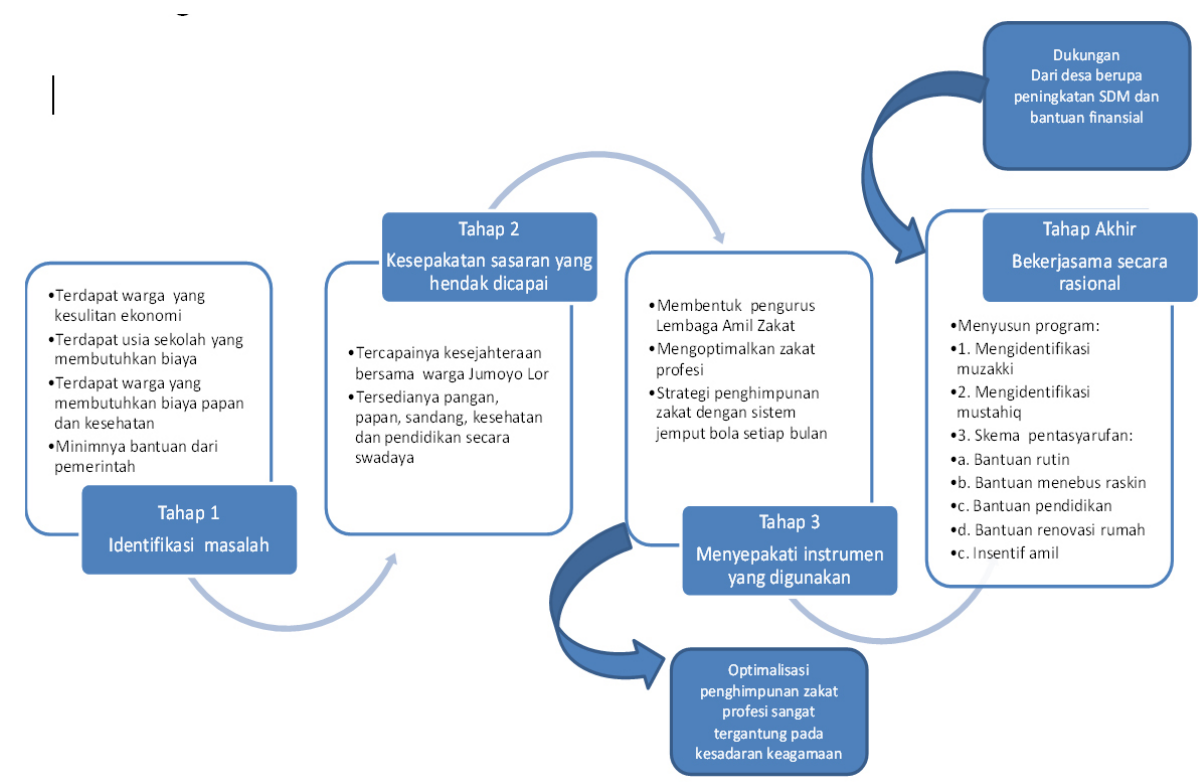

\section{Kesimpulan}

Community development dimaksudkanuntuk menciptakan kemandirian komunitas lokal untuk menata sosial ekonomi mereka sendiri, sehingga ketrgantungan terhadap negara berkurang. Mencermati praktek pengelolaan zakat profesi di Dusun Jumoyo Lor, telah terjadi pemberdayaan masyarakat dengan bertumpu pada kekuatan sendiri. Setidaknya kebutuhan dasar beras, kesehatan dan pendidikan telah dicoba untuk dipenuhi oleh masyarakat sendiri, meskipun dalam level yang sangat minimal.

Kendala yang dirasakan oleh para pengelola adalah kesadaran yang belum maksimal dari para muzakki. Dalam pandangan pengelola, potensi zakat di Dusun Jumoyo Lor baru mencapai 50\% sehingga masih memungkinkan bertambah. Potensi zakat juga dapat dikembangkan dalam program yang lebih produktif seperti untuk modal usaha, peternakan dan lain-lain. Namun gagasan itu masih sulit direalisasikan karena belum adanya tanggung jawab dan kejujuran dari para mustahiq. Proyek besar tersebut sampai saat ini masih menjadi angan-angan para pengurus LAZIS Jumoyo Lor, namun setidaknya apa yang telah dilakukan selama ini telah mengawali menciptakan masyarakat yang mandiri dengan menggali 
potensi dari warga itu sendiri. Proyek community development ini apabila dilakukan dalam sekala luas yaitu negara, maka akan memberikan dampak yang maha dahsyat, yaitu kemandirian bangsa.

\section{Daftar Pustaka}

Ali, Muhammad Daud. 1988. Sistem Ekonomi Islam Zakat dan Wakaf. Jakarta: UII Press.

Arikunto, Suharsimi. 1998. Prosedur Penelitian(suatu pendekatan praktek), cet. 11, Jakarta : PT Rineka Cipta.

Asnaini. 2008. Zakat Produktif dalam Perspektif Hukum Islam, Yogyakarta: Pustaka Pelajar.

Daniel, Moehar. 2003. Metode Penelitian Sosial Ekonomi, cet.2, Jakarta: Bumi Aksara.

Hafidhuddin, Didin. 2002. Zakat Dalam Perekonomian Modern, Jakarta: Gema Insani.

Kurde, Nukhtoh Arfawie. 2005. Memungut Zakat dan Infaq Profesi, Yogyakarta: Pustaka Pelajar.

Mannan, M. Abdul. 1995. Teori dan Praktek Ekonomi Islam (Islamic Economic: Theory and Praktice), Yogyakarta: Dana Bhakti Wakaf.

http://kertyawitaradya.wordpress.com/2010/01/26/tinjauan-teoritiscommunity-development/)

Prasetyo, Bambang dan Lina Miftahul Jannah. 2007. Metode Penelitian Kuantitatif: Teori dan Aplikasi, Jakarta: PT RajaGrafindo Persada.

Qardhawi, Yusuf. Tt. Fiqh az-Zakah, Bairut: Dar al-Irsyad.

Rahman, Afzalur. 1995. Doktrin Ekonomi Islam (Economics Doctrine of Islam), Yogyakarta: Dana Bhakti Wakaf

Ridwan, Muhammad. 2005. Manajemen Baitul Maal wa Tamwil (BMT), cet 2, Yogyakarta: UII Press. 
Soetomo. 2008. Strategi-strategi Pembangunan Masyarakat. Yogyakarta: Pustaka Pelajar.

Soetrisno, Loekman. 1995. Menuju Masyarakat Partisipatif. Yogtyakarta: Kanisius.

Supardi. 2007. Productive Zakat and Poverty Alleviation, Salatiga: Salatiga Press.

Sugiono. 2007. Metode Penelitian Kuantitatif-Kualitatif dan R\&D, set. III, Bandung: Alvabeta.

Undang-undang Zakat No.38 tahun 1999.

Zuhaili, Wahbah. 1985. al-Fiqh al-Islami wa Adillatuh. Damaskus: Darul Fikr. 